\title{
Research
}

\section{Bridging Human and Natural Sciences for a Better Understanding of Urban Floral Patterns: the Role of Planting Practices in Mediterranean Gardens}

\author{
$\underline{\text { Audrey Marco }}^{1}, \underline{\text { Carole Barthelemy }}^{1}, \underline{\text { Thierry Dutoit }}^{2}$, and Valérie Bertaudière-Montes $^{1}$
}

\begin{abstract}
Biodiversity research in urban settings constitutes an interdisciplinary field combining both the natural and human sciences. A full understanding of the patterns and processes underlying the dynamic of biodiversity in urban ecosystems needs to include humans in models of ecological functioning. We focus on the planting practices of gardeners to identify the bottom-up and top-down human influences on the floral diversity of the Mediterranean gardens in an urbanizing rural zone. An initial ecological study of cultivated flora in 120 private gardens showing floristic pattern variations along an urbanization gradient was combined with a sociological survey. This survey aimed at collecting reasons for planting in gardens in connection with cultivated species. These reasons were classified into categories and analyzed according to the frequency of cultivated species within the entire gradient. Floristic heterogeneity in gardens, represented by the richness of uncommon species, is predominantly caused by social factors, particularly related to the practices and social networks of gardeners who tend to diversify the range of species that are planted. Floristic uniformity, defined by a high frequency of occurrence of plant species, results not only from social factors but also from natural factors that exert high pressure in the Mediterranean region. This "floristic norm" is also influenced by the urban context, which can modify the expression of natural and social factors and lead to differences in plant species compositions between housing density zones. More generally, these results stress the importance of considering both individual choices and city-level influences through an interdisciplinary approach to understanding the underlying processes that establish urban biodiversity patterns at a small scale.
\end{abstract}

Key Words: environmental pressures; floristic heterogeneity; floristic norm; social network; urban biodiversity; urbanization gradient

\section{INTRODUCTION}

At the present time, increasing attention is being paid to the links between human well-being and ecosystem services. These ecosystem services include regulating services, e.g., control of climate and disease; provisioning services, e.g., production of food and fresh water; and supporting services, e. g., nutrient cycling or primary production (Millennium Ecosystem Assessment 2005). Studies now focus on the underlying mechanisms linking biodiversity with human health or social relations (de Vries et al. 2003, Maas et al. 2006, Andersson et al. 2007, Mitchell and Popham 2007). In cities, the importance of urban nature for human wellbeing and recreation has been clearly acknowledged
(Dunnett and Qasim 2000, Takano et al. 2002). A large number of species, including those that are rare and threatened, are found in the urban environment because of its high diversity of habitat types (Pyšek et al. 2004).

However, traditional nature conservation with strictly protected areas is hindered in urban areas by high population density in built-up surfaces and the consequent need for recreational areas (Colding et al. 2006). Biodiversity conservation, important for urban residents in addition to its intrinsic value, must deal with increasing population and urban sprawl. Consequently, urban ecological knowledge needs to be better integrated into the process of urban planning (Colding et al. 2006, Colding 2007, 
Kozlowski 2008). The understanding of urbanizing areas' biodiversity patterns is required to promote nature conservation within urban and peri-urban settings.

The first studies in ecology focusing on urban patterns of biodiversity relied on a traditional "gradient approach," explaining regular patterns of biodiversity in relation to varying levels of urbanization (McDonnell and Pickett 1990). However, this approach soon revealed some limitations because it failed to include directly the effects of social, economic, and cultural factors on urban patterns of biodiversity. Ecological theories and concepts cannot alone account for human influences on urban ecosystems. Therefore, interdisciplinary research involving both natural and social sciences is required to provide an integrated approach of ecology and biodiversity for urban planning (Parlange 1998, Collins et al. 2000, Grimm et al. 2000, McIntyre et al. 2000, Alberti et al. 2003, Lockaby et al. 2005, Shochat et al. 2006).

In this context, Martin et al. (2004) and Kinzig et al. (2005) have proposed a new conceptual framework based on "bottom-up" and "top-down" human influences. Bottom-up processes can be defined as "the integrated outcomes of small-scale (individual or household) choices or actions" (Kinzig et al. 2005: ). Urban biodiversity should vary by cultural, social, or economic characteristics. Top-down mechanisms "reflect city-level management strategies and decisions" (Kinzig et al. 2005: ). This framework goes beyond traditional gradient analysis and explains how humans affect biodiversity in urban environments. Information flows and activities are classified according to their degree of bottom-up and top-down influences. The effect of the socioeconomic or cultural characteristics of human residents on biodiversity patterns should vary in urban settings (Andersson et al. 2007).

The few studies that have examined bottom-up and top-down influences on urban biodiversity patterns have often been carried out on a large scale in public green spaces such as urban parks (Kinzig et al. 2005, Loeb 2006) and residential neighborhoods (Martin et al. 2004), or across a large metropolitan area (Iverson and Cook 2000, Hope et al. 2003). This scale is relevant to assess human effect at the city level. However, until now, most analyses on human influence have been based on socioeconomic and cultural variables, including residents' socioeconomic status and income levels, that do not allow a thorough understanding of the individual's interaction with his or her setting. To encompass human effect at a finer scale, we measured the social practices of urban residents. The exploration of individual choices or actions should provide further insights into how urban floral patterns are influenced by humans (Dow 2000).

Here, we aim to evaluate human influences on urban floral diversity, specifically in private gardens. Our focus is on planting practices and the gardeners' representations of flora, which we argue are key factors for garden floral patterns. In addition, private gardens are particularly appropriate for the study of top-down and bottom-up human influences on patterns of plant diversity. First, garden floral diversity largely results from bottom-up processes, including household landscaping choices and planting practices. Private gardening is particularly linked to personal tastes and pleasure, which differ according to the planted species. Sociological approaches have also shown the importance of gardening practices in some settings as a factor of social link (Dubost 1997), the individuals being part of a network of exchanges and donations. Second, there may also be some top-down control imposed by city-level management for landscaping practices (Martin et al. 2003) or by urban morphology, which sets the surface areas of dwellings with gardens (Smith et al. 2005, Acar et al.2007). Finally, gardens are well represented within urbanized landscapes (Gaston et al. 2005) and comprise important urban spaces in which people may interact daily with nature (Dunnett and Qasim 2000). Gardens cover about $2 \%$ of the surface of France (Bismuth and Merceron 2008). They play a key role in fauna-flora interactions (Chamberlain et al. 2004, Young 2008), endowing them with a high potential for urban biodiversity conservation.

In an earlier study, we examined the cultivated flora of 120 Mediterranean home gardens located along the urbanization gradient in an urbanizing rural zone (Marco et al. 2008). This initial ecological study highlighted variations in cultivated flora within the entire gradient and according to different zones of housing density (Marco et al. 2008). The majority of cultivated plants $(91 \%)$ had very low frequency values $(\mathrm{F}<20 \%)$, indicating high floristic heterogeneity over the entire urbanization gradient. Common species, characterized by a high frequency value within the entire gradient $(\mathrm{F}>20 \%)$, expressed a "floristic norm" at the garden level. 
They also displayed various floristic patterns depending on the type of urbanization. This preliminary analysis provided us with a floral baseline to question gardeners on cultivated plants. Using these data, our current research aims to assess the influence of both bottom-up and top-down human influences on garden flora. Further, we precisely determined the gardeners' planting choices in flora variations and evaluated their respective contribution to cultivated floral patterns.

We hypothesized that:

1. the introduction of cultivated species in private gardens is influenced by both natural and social factors. Like social factors, natural factors may particularly influence the gardeners' choices. In the Mediterranean region, natural factors create particularly high pressures for vegetation because of intense topo-edapho-climatic conditions such as summer drought and poor surface soil;

2. social and natural factors balance differently with regard to the floristic norm and floristic heterogeneity within the entire gradient; and

3. natural and social factors are shaped by the urban context, entailing different species' composition in each housing density zone.

To test these assumptions, we used an interdisciplinary approach based on sociological and ecological data. The garden represents a scientific study object, relevant for an interdisciplinary approach because both the ecologist, conducting ecological inventories, and the sociologist, surveying garden owners, can investigate a common spatial object (Mathieu 2006). Following the ecological inventory, a social survey was carried out among gardeners to collect the reasons for their plant choices. These reasons were associated with cultivated species and analyzed according to the frequency of these cultivated species and to land management. Combining sociological and ecological data will make it possible to directly link explanatory factors to observed floristic patterns, and will contribute to an understanding of the determinism of domestic floristic composition and patterns in urban areas.

\section{METHODS}

\section{Study site and sample gardens}

The study was conducted in the village of Lauris $\left(43^{\circ} 44^{\prime} \mathrm{N}, 5^{\circ} 18^{\prime} \mathrm{E}\right)$ in the western Mediterranean Basin in southeastern France (Fig. 1). This town is located within the Luberon Regional Nature Park, which is experiencing high urbanization pressure. It perfectly illustrates the demographic and land-use changes that are currently occurring in the French Mediterranean hinterland. Its population has doubled in the last 30 years, going from 1620 inhabitants in 1975 to 3257 inhabitants in 2005, within a surface area of 2181 ha (density:149 inhabitants $/ \mathrm{km}^{2}$ ).

In terms of landscape, Lauris' urban matrix can be divided into three housing density zones (Fig. 2) that define three major phases of the town's urbanization (Marco et al. 2008). Type 1 (T1) zone corresponds to the high-density housing zone (density > 20\%). It is located within the town's central village and is made up of small row houses built during the 12 th and 13 th centuries. Type 2 (T2) zone corresponds to the medium-density housing zone (density ranging from $10 \%$ to $20 \%$ ). It combines the two residential areas surrounding the village center that were constructed from 1965 to 1975 and is composed of semi-detached individual houses or row houses. Type 3a (T3a) zone corresponds to the low-density housing zone (density $<10 \%$ ) in the forest area. Villas in this area were constructed between 1975 and 1995 and are scattered in the Pinus halepensis (Aleppo pine) forest. Type $3 \mathrm{~b}$ (T3b) zone corresponds to the lowdensity housing zone (density $>10 \%$ ) in agricultural areas, characterized by modern villas constructed from 1990 to 2000 that are scattered over the village's former agricultural land.

The private garden is defined as any enclosed space, located outdoors but as a continuation of the house, in which the gardener organizes and manages plant life on a small scale. Therefore, the garden area comprises the area of the parcel minus the area of the house in square meters. In all, we sampled 120 gardens (Marco et al. 2008) along the urbanization gradient in 2005. To provide a homogeneous distribution of gardens, 30 houses from five main streets within each housing density type were chosen for survey. The entire length and both sides of each street were thoroughly examined, and every house was visited. With the residents' permission, 
Fig. 1. Map of study area indicating the village of Lauris within the Natural Regional Park of the Luberon in the French Mediterranean area.

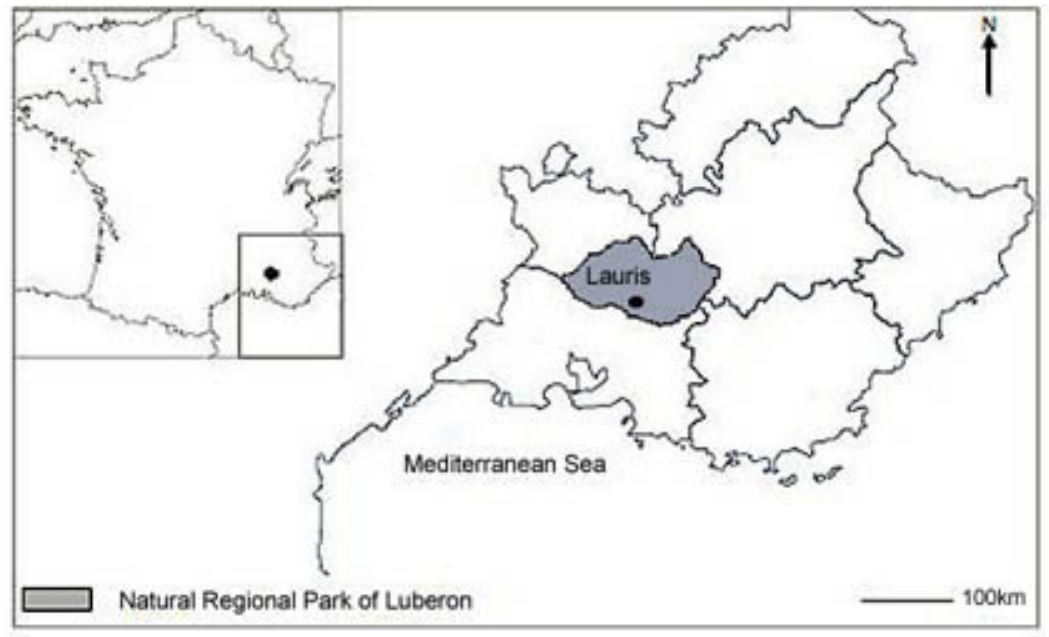

the survey was undertaken on the properties. We recorded 13 garden land covers including lawns, graveled paths, flower beds, pots and tubs, hedges, walls, borders of swimming pools, playing fields, pine forests, oak groves, orchards, vegetable gardens, and olive groves. An inventory of all the native and alien cultivated plants, excluding lawn grass, occurring on these land covers was drawn up. Further, the frequency of gardens including at least one individual of each species was calculated within the rural-urban gradient (frequency value 100\% = 120 gardens). Taxonomic identification was carried out on the basis of Brickell and Mioulane (2004).

\section{Sociological study}

A social survey was conducted among the 120 gardeners whose gardens had undergone flora inventories in 2008. Regarding socioeconomic status, gardeners were in the majority older persons and predominantly well-off pensioners who have retired in southern France in search of a sunny lifestyle and home ownership (Table 1). We surveyed the household member who took primary responsibility for the garden. A questionnaire, including open and closed questions, was designed by sociologists and ecologists to collect the various reasons given by gardeners for planting cultivated species. The main question asked was: Could you tell me why you plant this species in particular? Gardeners were questioned in their garden, and an exact reporting was made of their social statements concerning each species. In addition, other questions about failures in planting, gardening practices such as time spent in the garden, watering the garden, etc., were added to better understand the planting practices of those surveyed.

\section{Statistical analysis of data}

The gardeners' stated reasons for planting were classified and quantified by categories. This process was conducted by both ecologists and sociologists to avoid a discipline-biased categorization. When social statements regarding the same species referred to several categories, each social statement was classified in its respective category. These categories were also divided into two groups of factors, social and natural, to measure each factor's influence on the choice of cultivated species. Natural factors include biotope types such as climate, i.e., summer drought or winter frost, and soil, i.e., poor and superficial soil. Social factors 
Fig. 2. Housing density map and location of the 120 study gardens in Lauris, France. High-density housing type (built-up area $<20 \%$ ) corresponds to the center of Lauris (T1); medium-density housing type (built-up area 10\%-20\%) corresponds to two residential areas close to the center (T2); low-density housing type (built-up area $<10 \%$ ) corresponds to villas scattered in pine forest (T3a) or built on fallow land (T3b).

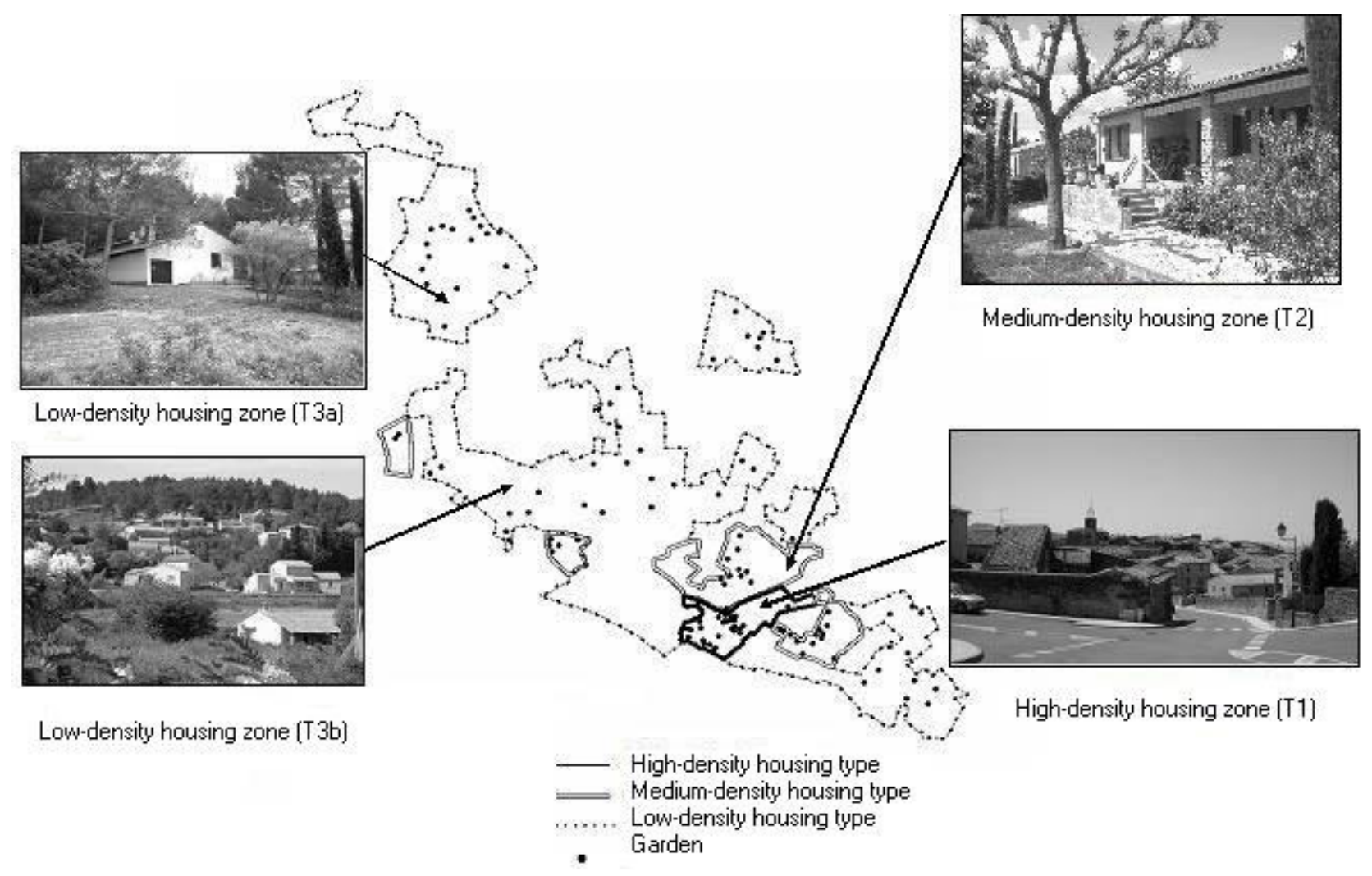

include esthetical considerations, donation or gift, and plant use (Appendix 1). Natural factors account for the cumulative percentage of the two categories related to biotope, i.e., "regional character" and "resistance-adaptation." All other mentioned categories are grouped under social factors.

Reasons for planting were analyzed by cultivated species frequency. A $\mathrm{Chi}^{2}$ test $(95 \%$ confidence interval) was used to detect any significant differences between the percentages of these two variables. The contribution of these natural and social factors to the establishment of common and uncommon species patterns was measured by calculating the percentage of natural and social factors for each group of species.
The "reasons for planting common species" categories, in percentage, were also examined according to housing density zones to assess the influence of the type of urbanization. $\mathrm{A} \mathrm{Chi}{ }^{2}$ test (95\% confidence interval) was used to detect any significant differences between the four zones. Similarly, the effect of natural and social factors in establishing common floristic patterns in each zone was calculated within each housing density zone.

Factorial Correspondence Analysis (FCA) was performed between the "reasons for planting" and the "common species" categories to identify the main relationships between these two variables. The low frequency of uncommon species by "reason for planting" does not permit us to carry out this 
Table 1. Social determinants of Lauris gardeners by housing density zone (frequency in \%). T1: highdensity housing type (built-up area $>20 \%$ ) corresponds to the center of Lauris; T2: medium-density housing type (built-up area 10-20\%) corresponds to two residential areas close to the center; T3a and T3b: lowdensity housing type (built-up area $<10 \%$ ) corresponds to villas scattered in pine forest or built on fallow land.

\begin{tabular}{|c|c|c|c|c|c|c|}
\hline \multirow[b]{2}{*}{ Variables } & \multirow[b]{2}{*}{ Categories } & \multirow[b]{2}{*}{ Total } & \multicolumn{4}{|c|}{ Housing density zones } \\
\hline & & & T1 high & $\begin{array}{c}\mathrm{T} 2 \\
\text { medium }\end{array}$ & $\begin{array}{l}\text { T3a low } \\
\text { (forest) }\end{array}$ & $\begin{array}{c}\text { T3b low } \\
\text { (agricultural) }\end{array}$ \\
\hline \multirow[t]{2}{*}{ Sex } & Male & 43 & 44 & 38 & 35 & 52 \\
\hline & Female & 57 & 56 & 62 & 65 & 48 \\
\hline \multirow[t]{4}{*}{ Age (years) } & $20-40$ & 1 & 0 & 0 & 0 & 5 \\
\hline & $41-60$ & 29 & 37 & 29 & 18 & 29 \\
\hline & $61-75$ & 33 & 30 & 14 & 65 & 29 \\
\hline & $>75$ & 37 & 33 & 57 & 18 & 38 \\
\hline \multirow[t]{3}{*}{ Marital status } & Married & 70 & 56 & 57 & 82 & 90 \\
\hline & Widowed & 27 & 33 & 43 & 18 & 10 \\
\hline & Single & 3 & 11 & 0 & 0 & 0 \\
\hline Move-in date & $<10$ & 28 & 37 & 33 & 18 & 19 \\
\hline \multirow[t]{2}{*}{ (years preceding survey) } & 10 to 20 & 21 & 19 & 5 & 18 & 43 \\
\hline & $>20$ & 51 & 44 & 62 & 65 & 38 \\
\hline \multirow[t]{3}{*}{ Place of residence } & Lauris & 16 & 33 & 10 & 0 & 14 \\
\hline & City in the south & 43 & 44 & 38 & 53 & 38 \\
\hline & Other city & 40 & 23 & 52 & 47 & 48 \\
\hline \multirow[t]{6}{*}{ Choice of Lauris } & Professional change & 23 & 37 & 17 & 12 & 25 \\
\hline & Retirement & 33 & 16 & 38 & 29 & 45 \\
\hline & Regional attraction & 15 & 16 & 17 & 18 & 10 \\
\hline & Family reasons & 18 & 32 & 13 & 18 & 10 \\
\hline & Fell in love & 8 & 0 & 4 & 24 & 5 \\
\hline & Other & 5 & 0 & 13 & 0 & 5 \\
\hline
\end{tabular}




\begin{tabular}{|c|c|c|c|c|c|c|}
\hline Socio-professional & Agriculture & 3 & 9 & 0 & 0 & 0 \\
\hline \multirow[t]{5}{*}{ category } & Artisan/trader & 15 & 9 & 21 & 25 & 10 \\
\hline & Highly educated professional & 23 & 14 & 21 & 25 & 33 \\
\hline & Intermediate professional & 21 & 9 & 21 & 19 & 33 \\
\hline & Employee & 36 & 55 & 29 & 31 & 24 \\
\hline & Laborer & 3 & 5 & 7 & 0 & 0 \\
\hline \multirow[t]{4}{*}{ Education } & No education & 19 & 37 & 24 & 0 & 5 \\
\hline & Primary & 36 & 30 & 38 & 41 & 38 \\
\hline & Secondary & 26 & 19 & 29 & 29 & 29 \\
\hline & More than secondary & 19 & 15 & 10 & 18 & 14 \\
\hline \multirow[t]{5}{*}{ Annual income $(€)$} & $<12,000$ & 9 & 15 & 14 & 0 & 5 \\
\hline & $12,000-30,000$ & 55 & 67 & 57 & 53 & 38 \\
\hline & $30,000-50,000$ & 23 & 15 & 14 & 35 & 33 \\
\hline & $>50,000$ & 8 & 4 & 0 & 12 & 19 \\
\hline & No response & 5 & 0 & 14 & 0 & 5 \\
\hline
\end{tabular}

statistical analysis. A two-way $62 \times 7$ contingency table was prepared. We placed the "common species" in the rows and the reasons for planting in the columns. A Monte Carlo permutation test based on 100 permutations was used to test the null hypothesis $(\mathrm{HO}=$ common species are not linked to reasons for planting). We used Minitab Software for Quality Improvement, version 14 (Minitab Inc., State College, Pennsylvania, USA), for data processing.

\section{RESULTS}

\section{Gardeners' stated reasons for planting}

In total, the gardeners stated 2248 reasons for planting 373 cultivated species. These statements were classified into 17 categories according to content (Appendix 1), and the frequencies of all categories were recorded (Fig. 3). The "esthetics" (R3) category had the highest percentage at $24 \%$. The "donation-gift" (R4) category accounted for
$18 \%$ of the statements. Thus, among all those surveyed, only $44 \%$ of the gardeners purchased more than $75 \%$ of the plants found in their gardens. The highest percentage was in zone $\mathrm{T} 3 \mathrm{~b}$, in which $62 \%$ of the gardeners purchased $75 \%$ of the plants $\left(\mathrm{Chi}^{2}=13.12, \mathrm{ddl}=6, P=0.047\right)$. The categories "use" (R6) at $12 \%$, and "previous presence in garden" (R13), at $11 \%$, were also greater than $10 \%$. Finally, the category "resistance-adaptation" (R2) of the plant accounted for $7 \%$ of the statements. In other words, within the entire gradient, natural factors accounted for $12 \%$ of the stated choices of planted species vs. $88 \%$ for social factors.

Concerning the question of constraints related to planting, we observed that the most frequently cited planting constraint along the urbanization gradient was "drought" (26\%). However, planting constraints differed according to housing density zones $\left(\mathrm{Chi}^{2}=63.59, \mathrm{ddl}=21, P=0000\right)$. Drought was most frequently cited in zones $\mathrm{T} 2$ and $\mathrm{T} 3 \mathrm{~b}$, compared with "cold" and "animals" (26\%) in zone T1 and "soil" (34\%) in zone T3a. Some $70 \%$ of the 
Fig. 3. Frequency distribution of categories for reasons given for planting by natural and social factors over the entire gradient. R1: regional character; R2: resistance-adaptation; R3: esthetics; R4: donationgift; R5: professional advice; R6: use; R7: propagation; R8: easy maintenance; R9: symbolism; R10: imitation; R11: remembrance; R12: specific flowering; R13: previous presence in garden; R14: past experimentation; R15: change; R16: usefulness for another plant; R17: other.

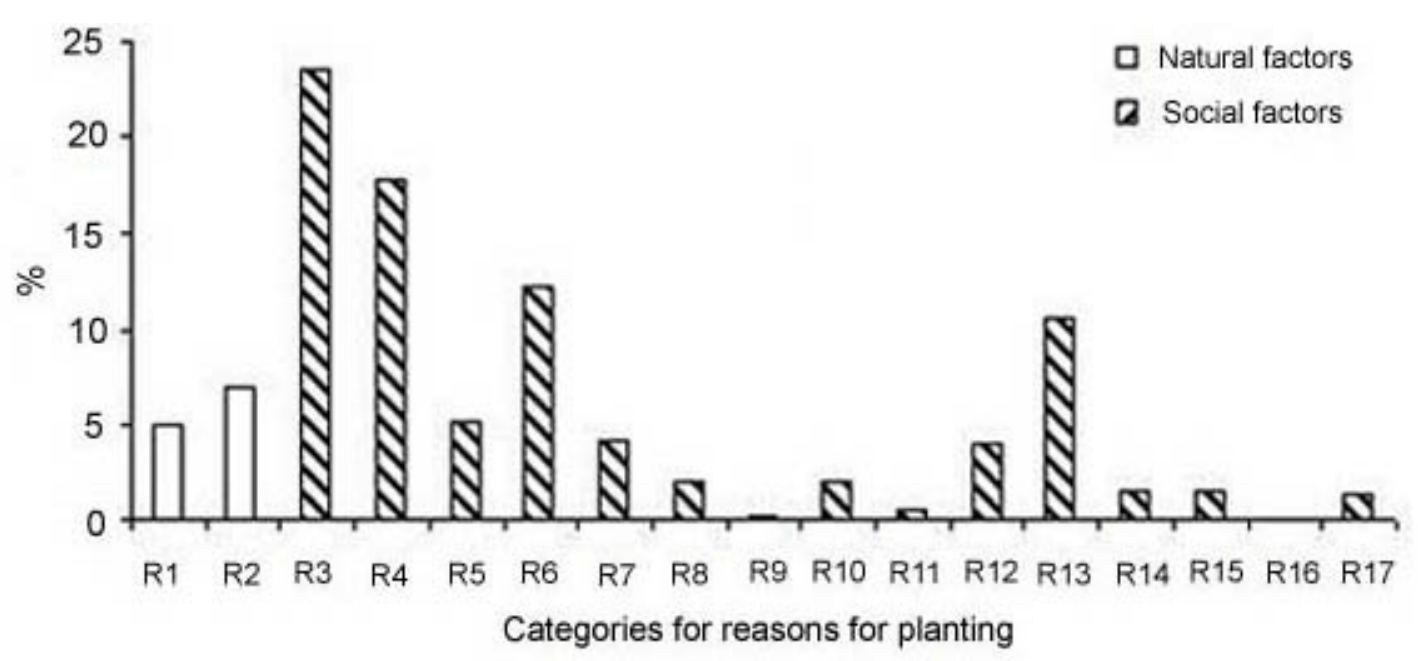

surveyed gardeners had at least one planting failure: $67 \%$ of the gardeners "did not replant anything" after a planting failure vs. $22 \%$ who replanted "a plant they had already tested."

\section{Reasons for planting and frequency of cultivated species}

We recorded the distribution of the categories of stated reasons for planting by species frequency over the entire gradient (Fig. 4). It was observed that the categories of stated reasons for planting differed significantly between common and uncommon species $\left(\mathrm{Chi}^{2}=120, \mathrm{ddl}=16, P<0.0001\right)$.

First, we observed qualitative differences. Among the "reasons for planting" categories with a frequency higher than 5\%, the "specific flowering" (R12) and "regional character" (R1) categories were related to common species, whereas "professional advice" (R5) and "propagation" (R7) were associated with uncommon species. However, both common and uncommon species are related to five "reasons for planting" categories with a frequency higher than 5\%, including the plant's "esthetics" (R3), "donation-gift" (R4), "previous presence in the garden" (R13), "use" (R6), and "resistanceadaptation"(R2).

Second, a quantitative difference can be highlighted. Among the five categories related to both common and uncommon species mentioned above, those referring to the plant's "esthetics" (R3), "resistance-adaptation" (R2), and "previous presence in garden"(R13) occurred at a much higher percentage for common species than for uncommon species. The "reasons for planting" categories connected to "donation-gift" (R4) and the plant's "use" (R6) occurred at a significantly higher percentage for uncommon species. Concerning species frequency, natural factors accounted for $16 \%$ of the choice of common species and $7 \%$ of the choice of uncommon species.

Results differed when the seven main "planting reasons" related to common species were analyzed according to housing density zones (Fig. 5). We noted that the categories concerning the plant's "esthetics" (R3) and "resistance-adaptation" (R2) 
Fig. 4. Frequency distribution of categories for reasons given for planting of cultivated species by common (in black) and uncommon (in white) species. R1: regional character; R2: resistance-adaptation; R3: esthetics; R4: donation-gift; R5: professional advice; R6: use; R7: propagation; R8: easy maintenance; R9: symbolism; R10: imitation; R11: remembrance; R12: specific flowering; R13: previous presence in garden; R14: past experimentation; R15: change; R16: usefulness for another plant; R17: other. * 95\% confidence interval.

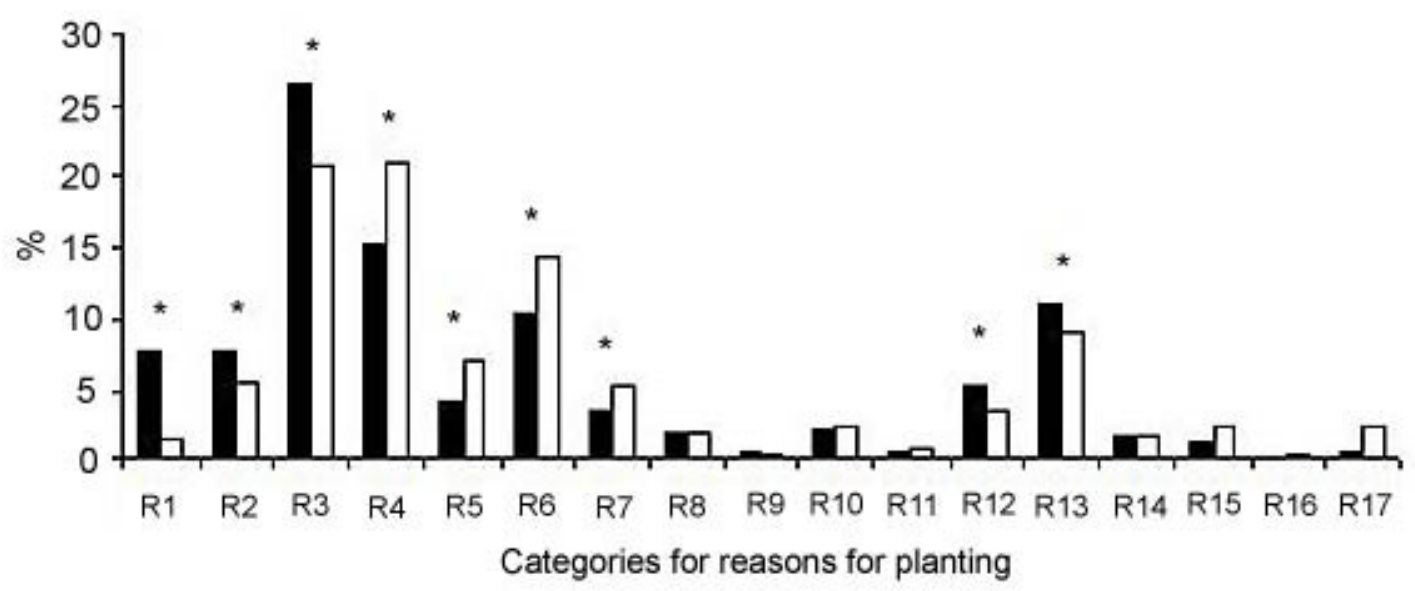

common species $(\mathrm{F}>20 \%) \quad$ uncommon species $(\mathrm{F}<20 \%)$

were significantly higher in zones $\mathrm{T} 1$ and $\mathrm{T} 3 \mathrm{a}\left(\mathrm{Chi}^{2}\right.$ $=14.54, \mathrm{ddl}=3, P=0.002 ; \mathrm{Chi}^{2}=12.56, \mathrm{ddl}=3$, $P=0.005)$. Moreover, "specific flowering" (R12) was a category that was significantly higher in zone T1 $\left(\mathrm{Chi}^{2}=10.98, \mathrm{ddl}=3, P=0.012\right)$, whereas the "use" (R6) category was significantly higher in zone $\mathrm{T} 3 \mathrm{~b}\left(\mathrm{Chi}^{2}=20.34, \mathrm{ddl}=3, P=0.000\right)$. In zone T2, the most significantly high category was R13, "previous presence in garden" $\left(\mathrm{Chi}^{2}=42.34, \mathrm{ddl}=\right.$ $3, P=0.000)$. Natural factors accounted for $18 \%$ of the choice of common species in zones T1 and T3a, $15 \%$ in zone $\mathrm{T} 2$, and $13 \%$ in zone T3b.

\section{Reasons for planting and plant species}

The common species are related to categories for specific planting reasons (Permutation Test, $\mathrm{Chi}^{2}=$ $1353.57, \mathrm{ddl}=366 ; p=0.000)$. The results of the Factorial Correspondence Analysis are presented for only the first three factors because they explained $80 \%$ of the variance. Factors 1 and 2 alone accounted for $58 \%$ of the variance (Fig. 6).
The first axis clearly separates those species associated with a plant's "use" considerations (R6), such as mulberry (Morus kagayamae), apricot (Prunus armeniaca), spearmint (Mentha viridis), cherry plum (Prunus cerastifera), the common fig (Ficus carica), and bay laurel (Laurus nobilis) from those linked to the plant's "esthetics" (R3) such as roses (Rosa sp.), petunias (Petunia sp.), "zonal" Pelargonium, and pansies (Viola $x$ wittrokiana). The second axis separates the species in the "donationgift" (R4) category, such as lily of the valley (Convallaria majalis), hens and chicks (Sempervivum tectorum), common ivy (Hedera helix), St. John's wort (Hypericum calycinum), Iris sp., common lilac (Syringa vulgaris), and marshmallow plant (Althaea sp.), from those connected to the plant's "esthetics" (R3) or to "regional character" (R1). R1 contributes to the second axis and more largely to the third axis. It groups together the regional species such as rosemary (Rosmarinus officinalis), Mediterranean cypress (Cupressus sempervirens), lavender (Lavandula angustifolia), olive (Olea europea), thyme (Thymus vulgaris), and oleander (Nerium oleander). On the other axes, forsythia 
Fig. 5. Frequency distribution of categories for reasons given for planting of common species by housing density zones (*95\% confidence interval).

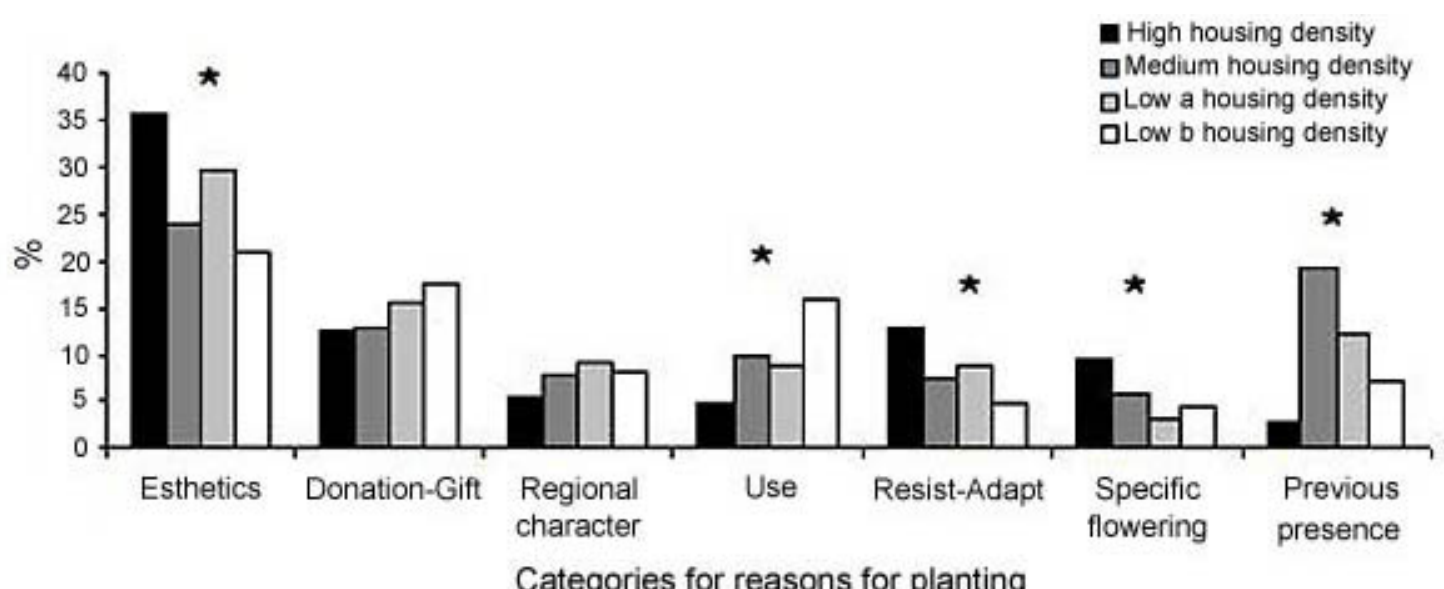

(Forsythia $x$ intermedia) and impatiens (Impatiens walleriana) are linked to the "specific flowering" (R12) category, whereas firethorn (Pyracantha sp.), juniper (Juniperus $x$ media), Leyland cypress $(x$ Cupressocyparis leylandii), and begonia (Begonia semperflorens) are linked to the "resistanceadaptation" (R2) category instead. The species associated with the "previous presence in garden" (R13) category are Arizona cypress (Cupressus arizonica) and Atlas Cedar (Cedrus atlantica).

\section{DISCUSSION}

\section{Planting practices linked to both social and natural factors}

The study of the planting practices of amateur gardeners in the Mediterranean hinterland demonstrated that the introduction of cultivated species in private gardens was influenced by both natural and social factors, with social factors predominating. The choice of cultivated species was highly dependent on the gardeners' tastes: "I like roses; they're beautiful." This attraction to beautiful plants is related to the decorative character of the garden, which has already been highlighted in sociological studies on the garden (Dubost 1997).

In addition, the choice was also influenced by the gardeners' social network. The traditional network of neighbors and kinship enables gardeners to acquire plants through exchange, and the garden becomes a center for sociability (Dubost 1997, Weber 1998, Nail 1999). The majority of cultivated species that are exchanged are species that multiply easily. Plants are also received as gifts for particular occasions, e.g., birthday or marriage, through this network. The importance of this social network in planting practices contributes to the diversification of the origins of cultivated species in gardens. It also plays a key role in the invasion process of ornamental plants. By preferring to exchange species that multiply easily, gardeners may strongly contribute to an increase in the species' geographic spread and potential to escape into neighboring public and wild lands.

Planting practices were also influenced by the gardeners' numerous uses (Gojard and Weber 1995 , Ubaud 1997, Blanckaert et al. 2004). The selected species can provide household food; protection 
Fig. 6. Two-dimensional graphical representation of the correspondence factorial map for common species and reasons for planting. R1: regional character; R2: resistance-adaptation; R3: esthetics; R4: donation-gift; R6: use; R12: specific flowering; R13: previous presence in garden. Alsp: marshmallow plant (Althaea sp.); Coma: lily of the valley (Convallaria majalis); Cuse: Mediterranean cypress (Cupressus sempervirens); Fica: common fig (Ficus carica); Hehe: common ivy (Hedera helix); Hyca: St. John's wort (Hypericum calycinum); Irsp: Iris sp.; Sete: hens and chicks (Sempervivum tectorum); Syvu: common lilac (Syringa vulgaris); Lano: bay laurel (Laurus nobilis); Laan: lavender (Lavandula angustifolia); Mevi: spearmint (Mentha viridis); Moka: mulberry (Morus kagayamae); Neol: oleander (Nerium oleander); Oleu: olive (Olea europea); Pezo: "zonal” Pelargonium; Pesp: Petunia sp.; Prar: apricot (Prunus armeniaca); Prce: cherry plum (Prunus cerastifera); Rosp: rose (Rosa sp.); Roof: Rosemary (Rosmarinus officinalis); Thvu: thyme (Thymus vulgaris); Viwi: pansy (Viola x wittrokiana).

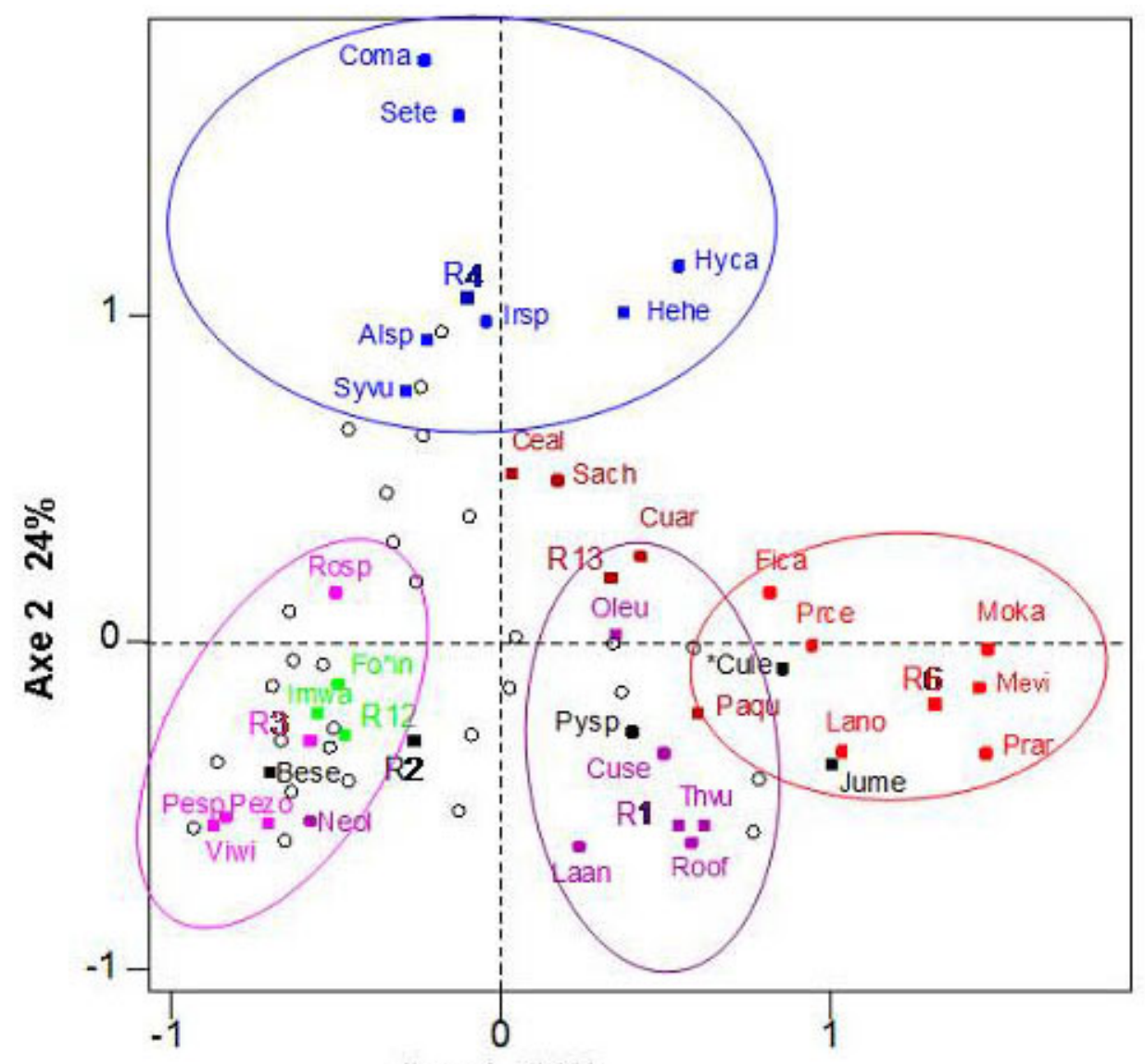

Axe $134 \%$ 
from the sun, wind, or the view of others; enclose a space; or maintain the soil. Although the utilitarian consideration was often attributed to country habits, it was also found in urban private gardens in which pleasure and utility co-existed (Dubost 1997). Nevertheless, cultivating fruits and vegetables was done more for seasonal pleasure than for subsistence (Dubost 2008).

However, plant choice was influenced by the local topo-edapho-climatic constraints, and the contribution of natural factors was greater than $10 \%$. The gardeners, frequently faced with planting failures, had to choose species that were adapted to these environmental pressures. They also kept species that were already present in their gardens because these species had succeeded in maintaining themselves over time, testifying to resistance vis-àvis the constraints in the biotope. This awareness of species resistance at the time of planting was also found indirectly in the practice of exchanging plants. The exchanged species were not only easy to propagate from cuttings but also grew well: "It's true that I had some advice from my mother who had the same type of soil as me so she provided species that had done well at her house."

The domestication of plants in a constrained setting results from a compromise between environmental pressures and socially developed values and tastes. This was clearly demonstrated by several UK studies of domestic garden flora, which underscored the strong influence that human factors have on domestic diversity patterns (Nail 1999, Loram et al. 2008). At a larger scale, the domestication of plants will also depend on economic constraints. Other considerations not recorded in our study, such as the availability of cultivated plants in nurseries and the price of plants, could influence gardeners' planting choices and thus be involved in floristic uniformity rather than floristic diversification. The understanding of the role of these factors opens new perspectives on interdisciplinary research combining natural, social, and economic sciences.

\section{Effect of natural and social factors on floristic norm and floristic heterogeneity}

The floristic norm for Mediterranean gardens, illustrated by patterns of common species, results mainly from a compromise between social and natural factors. Natural factors contribute more to establishing the floristic norm than the floristic heterogeneity. Thus, as with the natural flora in the Mediterranean region, the cultivated flora of gardens is shaped by drastic topo-edapho-climatic conditions in this setting. Gardening practices cannot totally set aside biotope constraints. Surprisingly for sociologists, the floristic norm in gardening practices results not only from social factors but also from natural constraints. This result corroborates the theoretical assumption developed by environmental sociology that social forms are partially dependent on natural constraints (Picon 1988). Conversely, floristic heterogeneity in Mediterranean gardens, illustrated by the high frequency of uncommon species, results from a compromise in which social factors prevail. The gardeners' plant use and social network have favored the diversification of planted species. We stress that social factors lead to the diversification of domestic garden flora, whereas natural factors have a greater imprint on the floristic standardization of gardens.

\section{Influence of the type of urbanization on the floristic norm}

The analysis of the patterns of common species within each housing density zone showed that the type of urbanization also affected the compromise establishing the floristic norm. In the high-density housing zone, $87 \%$ of the gardens are located in the front yard, and $77 \%$ are surrounded by walls (Marco et al., unpublished data). Frequently viewed by passers-by in this tourist village, the gardens take on a demonstrative role (Dubost 1997, Atelier parisien d'urbanisme 2006). The need for "nature" is felt everywhere in this mineral-rich urban setting (Dunnett and Qasim 2000), and gardeners want to brighten up their neighborhood by choosing colorful plants with a long-lasting blooming period. However, because of the types of buildings and pollution, the urban environment creates high pressure on flora. In the center of the town, made up of tall row houses located in very narrow streets, the gardens are submitted to highly contrasting levels of sunlight. Urban pollution, particularly because of stray cats, constitutes additional constraints for planting cultivated species. The resistance of plants vis-à-vis these environmental pressures, which is expressed by a higher contribution of natural factors in the floristic patterns of common species, is a major criterion for choice in planting. 
In the medium-density housing zone, the cultivated species tend to be the planting choices of previous gardeners. Some $38 \%$ of the gardens in this zone were already laid out before the surveyed gardeners moved in, and the previous landscape design was kept. In the 1960s and 1970s, this predominantly suburban area constituted the village's first urban expansion, attracting the first retired couples who came to settle in the Mediterranean hinterland. Currently, this area includes widows but also working couples and young people, renters of existing houses, who are contributing to the start of population renewal in this area. Having inherited the cultivated flora of these gardens, these renters have planted fewer plants, with $43 \%$ of them having purchased less than a quarter of the present plants in their gardens. This type of urbanization also shows the importance of single-species hedges in gardens, exemplifying the trends of the 1970 s and 1980s (Ubaud 1997).

In the forest zone with low housing density, the presence of the pine tree forest constitutes a setting with low species diversification and is considered as esthetically monotone because of the dominance of the pine's green color. The plant choice is highly determined by the plant's esthetics as well as its resistance to the particularly high edaphic pressures or acidic topsoil. In the agricultural zone with low housing density, common and uncommon species choices are closely linked to plant use. The well-off gardeners from this zone have large gardens $(2500$ $\mathrm{m}^{2}$ ) laid out on previous agricultural fields, and $43 \%$ have a space devoted to vegetable gardens (Marco et al., unpublished data). The gardens display species for their useful properties, i.e., casting shade and supplying food. Moreover, gardeners preserve old trees such as Prunus cerasifera, $P$. armeniaca, and grape vines (Vitis sp.) in their gardens, which are remainders of past agricultural activities, e.g., cherry orchards, olive groves, and vineyards. The history of land use also seems to determine the distribution and composition of horticultural flora in this housing density zone.

\section{CONCLUSION}

Interesting insights are provided into the factors that drive ornamental plant patterns in private green spaces. Although characterized by wide horticultural diversity, cultivated flora also shows similar species composition between gardens of the same housing density type. The understanding of the underlying processes that establish urban floral patterns must focus on both bottom-up and top-down influences through interdisciplinary approaches. In the Mediterranean area, the diversity of patterns of domestic gardens is largely controlled by bottomup processes. Planting choices result from a compromise between what is "socially constructed" and what is "naturally possible." Hence, the heterogeneity of cultivated flora in gardens is predominantly influenced by social factors, such as gardeners' uses and social network, that tend to diversify the range of planted species. Floristic uniformity is not only the result of social factors but also the expression of natural factors that exert high pressure in this context. Furthermore, top-down processes also influence cultivated floral patterns. The urban context, because of its structure and history, can shape the expression of natural and social factors and lead to differences in species composition in each housing density zone. Regarding the composition and mechanisms of human-generated floral diversity, the cultivated flora seems to provide more social services, such as esthetics and social links, than ecological services in urban systems. The "flower garden" remains the dominant model of private garden, inherited from the traditional "garden à la française." A functional approach is needed to improve our knowledge of the interspecific relationships among horticultural flora and to better understand their interaction with the wider environment, in particular the ways in which they provide environmental benefits for urban areas as well as ecosystem services such as air filtering, micro-climate regulation, noise reduction, rainwater drainage, and sewage treatment. Furthermore, our findings point out how important it is for future research to deepen our understanding of how natural and social factors contribute to urban biodiversity patterns through studies in contrasting social and environmental contexts. This will provide a better knowledge of the processes by which urban biodiversity is related to human influences. The importance of the traditional neighborhood and kinship network in planting practices also opens new perspectives for interdisciplinary research to understand the flow of cultivated species between gardens and, on a broader scale, the dynamic of domestic diversity in these urbanized contexts. 
Responses to this article can be read online at:

http://www.ecologyandsociety.org/vol15/iss2/art2/responses/

\section{Acknowledgments:}

This research was carried out within the framework of a Ph.D. thesis and financially supported by the French Association pour le Développement de l'Enseignement et des Recherches. We sincerely thank the town of Lauris as well as all the inhabitants who participated in this study. The authors also thank Sharon Calandra and Florence Waïtzenegger for language edition of the manuscript, as well as Carl Folke and two anonymous reviewers for proposing significant improvements to our manuscript.

\section{LITERATURE CITED}

Acar, C., H. Acar, and E. Eroglub. 2007. Evaluation of ornamental plant resources to urban biodiversity and cultural changing: a case study of residential landscapes in Trabzon city (Turkey). Building and Environment 42:218-229.

Alberti, M., J. M. Marzluff, E. Shulenberger, G. Bradley, C. Ryan, and C. Zumbrunnen. 2003. Integrating humans into ecology: opportunities and challenges for studying urban ecosystems. Bioscience 53:1169-1179.

Andersson, E., S. Barthel, and K. Arhné. 2007. Measuring social-ecological dynamics behind the generation of ecosystem services. Ecological Applications 17:1267-1278.

Atelier parisien d'urbanisme. 2006. Atlas de la nature à Paris. Le Passage, Paris, France.

Bismuth, V., and E. Merceron. 2008. L'observatoire des papillons des jardins. Muséum national d'Histoire naturelle, Paris, France.

Blanckaert, I., R. L.Swennen, M. Paredes Flores, R. Rosas Lopez, and R. Lira Saade. 2004. Floristic composition, plant uses and management practices in home gardens of San Rafael Coxcatlan, Valley of Tehuacan-Cuicatlan, Mexico. Journal of Arid Environments 57:39-62.
Brickell, C., and P. Mioulane. 2004. Encyclopédie des 15000 plantes et fleurs de jardin. Larousse, Paris, France.

Chamberlain, D. E., A. R. Cannon, and M. P. Toms. 2004. Associations of garden birds with gradients in garden habitat and local habitat. Ecography 27:589-600.

Colding, J. 2007. Ecological land-use complementation for building resilience in urban ecosystems. Landscape and Urban Planning 81:46-55.

Colding, J., J. Lundberg, and C. Folke. 2006. Incorporating green-area user groups in urban ecosystem management. Ambio 35:237-244.

Collins, J. P., A. P. Kinzig, N. B. Grimm, W. F. Fagan, D. Hope, J. Wu, and E. T. Borer. 2000. A new urban ecology. American Scientist 88:416-425.

de Vries, S., R. A. Verheij, P. Groenewegen, and P. Spreeuwenberg. 2003. Natural environmentshealthy environments? An exploratory analysis of the relationship between greenspace and health. Environment and Planning 35:1717- 1731.

Dow, C. 2000. Social dimensions of gradients in urban ecosystems. Urban Ecosystems 4:255-275.

Dubost, F. 1997. Les jardins ordinaires. Réédition de Côté jardins, 1984. L'Harmattan, Paris, France.

Dubost, F. 2008. Les français et leurs jardins. Encyclopaedia Universalis, Universalia, Paris, France.

Dunnett, N., and M. Qasim. 2000. Perceived benefits to human well-being of urban gardens. HortTechnology 10:40-45.

Gaston, K. J., P. H. Warren, K. Thompson, and R. M. Smith. 2005. Urban domestic gardens (IV): the extent of the resource and its associated features. Biodiversity and Conservation 14:3327-3349.

Gojard, S., and F. Weber. 1995. Jardins, jardinage et autoconsommation alimentaire. INRA Sciences Sociales 2:1-4.

Grimm, N. B., M. J. Grove, S. T. A. Pickett, and C. L. Redman. 2000. Integrated approaches to long term studies of urban ecological systems. Bioscience 50:571- 584 . 
Hope, D., C. Gries, W. Zhu, W. F. Fagan, C. L. Redman, N. B. Grimm, A. L. Nelson, C. Martin, and A. Kinzig. 2003. Socioeconomics drive urban plant diversity. Proceedings of the National Academy of Sciences 100:8788-8792.

Iverson, L. R., and E. A. Cook. 2000. Urban forest cover of the Chicago region and its relation to household density and income. Urban Ecosystems 4:105-124.

Kinzig, A. P., P. Warren, C. Martin, D. Hope, and M. Katti. 2005. The effects of human socioeconomic status and cultural characteristics on urban patterns of biodiversity. Ecology and Society 10(1): 23. [online] URL: www.ecologyandsociety.org/ vol10/iss $1 / \operatorname{art} 23 /$.

Kozlowski, G. 2008. Urban biodiversity: search for new concepts and approaches for better understanding of urban ecosystems. Pages 277-286 in L. Monteventi Weber, C. Deschenaux, and M. Tranda-Pittion, editors. Campagne-ville: le pas de deux. Enjeux et opportunités des recompositions territoriales. Presses polytechniques et universitaire romandes (PPRU), Lausanne, Switzerland.

Lockaby, B. G., D. Zhang, J. McDaniel, H. Tian, and S. Pan. 2005. Interdisciplinary research at the urban-rural interface: the WestGa project. Urban Ecosystems 8:7-21. [online] URL: http://www.aubu rn.edu/ lockabg/pdfs/2005\%20Urban \%20Ecosystems\% 208\%207-21.pdf.

Loeb, R. E. 2006. A comparative flora of large urban parks: intraurban and interurban similarity in the megalopolis of the northeastern United States. Journal of the Torrey Botanical Society 133:601-625.

Loram, A., K. Thompson, P. H. Warren, and K. J. Gaston. 2008. Urban domestic gardens (XII): the richness and composition of the flora in five cities. Journal of Vegetation Science 19:321-330.

Maas, J., R. A. Verheij, P. P. Groenewegen, S. de Vries, and P. Spreeuwenberg. 2006. Green space, urbanity, and health: how strong is the relation? Journal of Epidemiology and Community Health 60:587-592.

Marco, A., T. Dutoit, M. Deschamps-Cottin, J.F. Mauffrey, M. Vennetier, and V. Bertaudière-
Montès. 2008. Gardens in urbanizing rural areas reveal an unexpected floristic diversity related to housing density. Comptes Rendus Biologies 331:452-465.

Mathieu, N. 2006. Pour une construction interdisciplinaire du concept de milieu urbain durable. Natures Sciences Sociétés 14:376-382.

Martin, C. A., K. A. Peterson, and L. B. Stabler. 2003. Residential landscaping in Phoenix, Arizona, U.S.: practices and preferences relative to covenants, codes, and restrictions. Journal of Arboriculture 29:9-17.

Martin, C. A., P. S. Warren, and A. P. Kinzing. 2004. Neighborhood socio-economic status is a useful predictor of perennial landscape vegetation in residential neighborhoods and embedded small parks of Phoenix, AZ. Landscape and Urban Planning 69:355-368.

McDonnell, M. J., and S. T. A. Pickett. 1990. Ecosystem structure and function along urban-rural gradients: an unexploited opportunity for ecology. Ecology 71:1232-1237.

McIntyre, N. E., C. Knowles-Yanez, and D. Hope. 2000. Urban ecology as an interdisciplinary field: differences in the use of "urban" between the social and natural sciences. Urban Ecosystems 4:5-24.

Millennium Ecosystem Assessment. 2005. Ecosystems and human well-being: synthesis. Island Press, Washington, D.C., USA.

Mitchell, R., and F. Popham. 2007. Greenspace, urbanity and health: relationships in England. Journal of Epidemiology and Community Health 61:681-683.

Nail, S. 1999. Jardiniers anglais, entre conformisme et création. Pages 47-77 in H. Brunon, editor. Le jardin notre double. Editions Autrement, Paris, France.

Parlange, M. 1998. The city as ecosystem. Bioscience 48:581-585.

Picon, B. 1988. L'espace et le temps en Camargue. Actes Sud, Arles, France.

Pyšek, P., Z. Chocholoušková, A. Pyšek, V. Jarošík, M. Chytrý, and L. Tichý. 2004. Trends 
in species diversity and composition of urban vegetation over three decades. Journal of Vegetation Science 15:781-788.

Shochat, E., P. S. Warren, S. H. Faeth, N. E. McIntyre, and D. Hope. 2006. From patterns to emerging processes in mechanistic urban ecology. Trends in Ecology and Evolution 21:186-191.

Smith, R. M., K. J. Gaston, P. H. Warren, and K. Thompson. 2005. Urban domestic gardens (V): relationships between landcover composition, housing and landscape. Landscape Ecology 20:235-253.

Takano, T., K. Nakamura, and M. Watanabe. 2002. Urban residential environments and senior citizens' longevity in megacity areas: the importance of walkable green spaces. Journal of Epidemiology and Community Health 56:913-918.

Ubaud, J. 1997. Des arbres et des hommes, architecture et marqueurs végétaux en Provence et Languedoc. Edisud, Aix-en-Provence, France.

Weber, F. 1998. L'honneur des jardiniers; les potagers dans la France du XXeme siècle. Belin, Paris, France.

Young, C. 2008. Butterfly activity in a residential garden. Urban Habitats 5:84-102. 
Table A-1. Categories for reasons for planting given by the gardeners and divided into natural and social factors.

\begin{tabular}{ll}
\hline \hline Type of factors & $\begin{array}{l}\text { Categories for reasons for planting } \\
\text { (with abbreviation) }\end{array}$
\end{tabular} Corresponding social statements

Natural factors Regional character (R1)

Resistance-adaptation (R2)

Social factors $\quad$ Esthetics (R3)

Donation-gift (R4)

Professional advice (R5)

Use (R6)

Propagation (R7)

Easy maintenance (R8)

Symbolism (R9)

Imitation (R10)

Remembrance (R11)
"It's the local tree, the oleander."

"It comes from here!"

"It's typical of the climate and region."

"Because it is resistant."

"Because it does well in limestone."

"It doesn't need too much water."

"I like roses; they're beautiful."

"It's pretty; it makes a beautiful cascade."

"Because I like the scent a lot."

"The neighbor gave it to me."

"It was given to me for May 1st."

"It's a gift from my daughter-in-law."

"The gardener recommended it to us."

"The tree nursery person planted it."

"To reduce the view into my bathroom window."

"Because that holds back the soil."

"To make jam preserves."

"I took it from the countryside over there."

"That was picked up along the Rhone."

"I picked it up in Cassis, along the road."

"Because it does not need maintenance."

"Because it's practical."

"We didn't want any maintenance so we put that in front."

"In the Vaucluse, they say every house needs to have a linden tree."

"Because it fits in with a kind of tradition, triangularity."

"Because I saw many of them in Cannes."

"I saw it in a catalogue."

"Since the neighbor had it, we put one in."

"It reminds me of the large flowers in Africa where I lived."

"It's a pension souvenir." 
Specific flowering (R12)

Previous presence in garden (R13)

Past experimentation (R14)

Change (R15)

Usefulness for another plant (R16)

Other (R17)
"For the early flowers."

"Because it was supposed to flower all year."

"It comes back every year."

"The hedge was already there."

"The previous owner was the one who planted it."

"I brought it from my last house."

"We had some at my other house in Rambouillet."

"Because it was to change the type of foliage."

"That changes the color of the pines somewhat."

"To vary the shapes in the rock garden."

"It's to create humidity for my bonsais."

"I put it there because of the ants around the apple tree."

"Because we thought it was boxwood."

"Because it wasn't expensive." 